TAPROBANICA, ISSN 1800-427X. November, 2020. Vol. 09, No. 02: pp. 220-221, pl. 60.

(C) Research Center for Climate Change and Department of Biology, Faculty of Mathematics \& Natural Sciences, University of Indonesia, Depok 16424, INDONESIA.

http://www.taprobanica.org/

https://doi.org/10.47605/tapro.v9i2.235

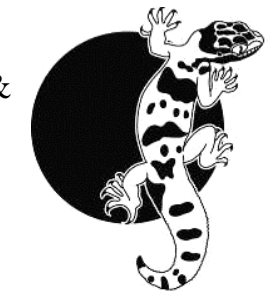

\section{Limnonectes macrodon (Duméril \& Bibron, 1841) from Bali, Indonesia}

The Giant Javan Frog, Limnonectes macrodon (Duméril \& Bibron, 1841), is a large dicroglossid with adult males reaching up to 15 cm SVL (Iskandar 1998). This species was previously thought to be widespread in Southeast Asia, but taxonomic studies have spilt the taxon into multiple species, with $L$. macrodon now considered to be restricted to Java and to Lampung province in South Sumatra (Iskandar 1998, Frost 2020). Accordingly, numerous records from elsewhere are now considered either to belong to other taxa or need further verification (Frost 2020). For example, those records from the Malay Peninsula (Berry 1975) and from the mainland of Southeast Asia are now referrable to L. blythii (Stuart et al. 2008), whereas those from Borneo are referrable to L. ingeri (Frost 2020). The record from Sikkim in northeastern India by Chanda (1987) is almost certainly in error (Dutta 1997), whereas another record for Manipur in northeastern India (Devi \& Shamungou 2006) is yet to be verified. Similarly, those from New Guinea also need further investigation (Menzies 2006) and a record from the Andaman Islands in India likely belongs to an as yet undescribed species (Stuart et al. 2008).

While the likelihood of $L$. macrodon occurring in Bali has been mentioned before (Somaweera 2020), this is the first photographic evidence of the species from the island. On 1 March 2020 at 19:30 h, an adult specimen of $L$. macrodon with an estimated SVL of $10 \mathrm{~cm}$ (Fig. 1) was photographed by PS on a bank of a stream close to Pura Gunung Lebah at Ubud in Gianyar Province, Bali $\left(8^{\circ} 30^{\prime} 12.0^{\prime \prime} \mathrm{S}\right.$, $115^{\circ} 15^{\prime} 18.0^{\prime \prime}$ E). Located within a deeply carved valley, the stream had steep banks and was covered with dense-canopy vegetation (Fig. 2). The specimen was located on the wet floor covered with leaf litter close to water. The elevation of the location is approximately $190 \mathrm{~m}$ a.s.l. The specimen was identified on the basis of external morphological features as per Manthey and Grossmann (1997) and Iskandar (1998), and the identity was confirmed by D. Iskandar based on images taken. Only one specimen of $L$. macrodon was observed at the site.

To date, 15 species of amphibians are known from Bali Island including four species of dicroglossid frogs (McKay 2006, Somaweera 2020). Within the known range on Java and Sumatra L. macrodon usually occupies flowing water bodies in densely vegetated areas up to $700 \mathrm{~m}$ a.s.1., which agrees with the habitat from which the Bali specimen was recorded. However, this species is also known to occur in man-made habitats such as paddy fields and ponds (Kusrini 2005). The origin of the Bali population of L. macrodon is unclear. While it is possible that this frog species remained unnoticed in Bali until now, there is also a possibility that it was introduced to Bali recently via the frog meat industry. American bullfrogs (Lithobates catesbeianus) that were used in the frog meat industry are now naturalised in Bali (Somaweera et al. 2018). The large-sized Limnonectes macrodon is widely collected for human consumption in Java (Indonesia), and can be expected to be traded across adjacent islands (Kusrini 2005).

\section{Acknowledgements}

We thank Djoko Iskandar for helping to identify the species based on the images we provided and the reviewers for constructive feedback.

\section{Literature cited}

Berry, P.Y. (1975). The Amphibian Fauna of Peninsular Malaysia. Tropical Press, Kuala Lumpur: $130 \mathrm{pp}$.

Chanda, S.K. (1987). On a collection of anuran amphibians from Darjeeling and Sikkim Himalayas, with description of a new species of Rana (Ranidae). Journal of the Bengal Natural History Society (New Series) 5 (2): 140-151.

Devi, Y.B. and K. Shamungou (2006). Amphibian fauna of Manipur State, India. Journal of Experimental Zoology, 9: 317-324. 
Duméril, A.M.C., and Bibron, G. (1841) Erpétologie Genérale ou Histoire Naturelle Complète des Reptiles. Volume 8. Librarie Enclyclopedique de Roret, Paris: 447 pp.

Dutta, S.K. (1997). Amphibians of India and Sri Lanka (Checklist and Bibliography). Odyssey Publishing House, Orissa: 342 pp.

Frost, D.R. (2020). Amphibian Species of the World: An Online Reference. Version 6.1. <https://amphibiansoftheworld.amnh.org/inde x.php> Accessed on 19 October 2020.

Iskandar, D.T. (1998). The Amphibians of Java and Bali. Lipi - The Field Guide Series. Research and Development Centre for Biology Lipi, Bogor: 117 pp.

Kusrini, M.D. (2005). Edible frog harvesting in Indonesia: evaluating its impact and ecological context. Ph.D. Dissertation, James Cook University: $256 \mathrm{pp}$.

Manthey, U. and W. Grossmann (1997). Amphibien \& Reptilien Südostasiens. Natur und Tier, Münster: $512 \mathrm{pp}$.

McKay, J.L. (2006): A Field Guide to the Amphibians and Reptiles of Bali. Krieger Pub., Florida: $138 \mathrm{pp}$.

Menzies, J.I. (2006). The Frogs of New Guinea and the Solomon Islands. Pensoft, Moscow: $345 \mathrm{pp}$.
Somaweera, R. (2020). A Naturalist's Guide to the Reptiles \& Amphibians of Bali. $2^{\text {nd }}$ Edition. John Beaufoy Publishing, London: 176 pp.

Somaweera, R., R. Lilley, A. Putra, P. Ganz, P.N. Govendan, J.L. McKay, and O. Milenkaya (2018). Recent additions to the herpetofauna diversity of the island of Bali, Indonesia. Sauria, 40 (1): 75- 86.

Stuart, S.N., M. Hoffmann, J. Chanson, N. Cox, R. Berridge, P. Ramani, and B. Young (2008). Threatened Amphibians of the World. Conservation International, Arlington, Virginia; International Union for the Conservation of Nature, Gland; and Lynx Editions, Barcelona: $758 \mathrm{pp}$.

Submitted: 25 June 2020, Accepted: 31 October 2020 Section Editor: Thasun Amarasinghe

Petr Sramek ${ }^{1} \&$ Ruchira Somaweera ${ }^{2}$

${ }^{1}$ Brno Zoo, Brno, 635 00, Czech Republic ${ }^{2}$ CSIRO Health and Biosecurity, Floreat, WA 6014, Australia

${ }^{2}$ E-mail: ruchira.somaweera@gmail.com 


\section{Plate 60}

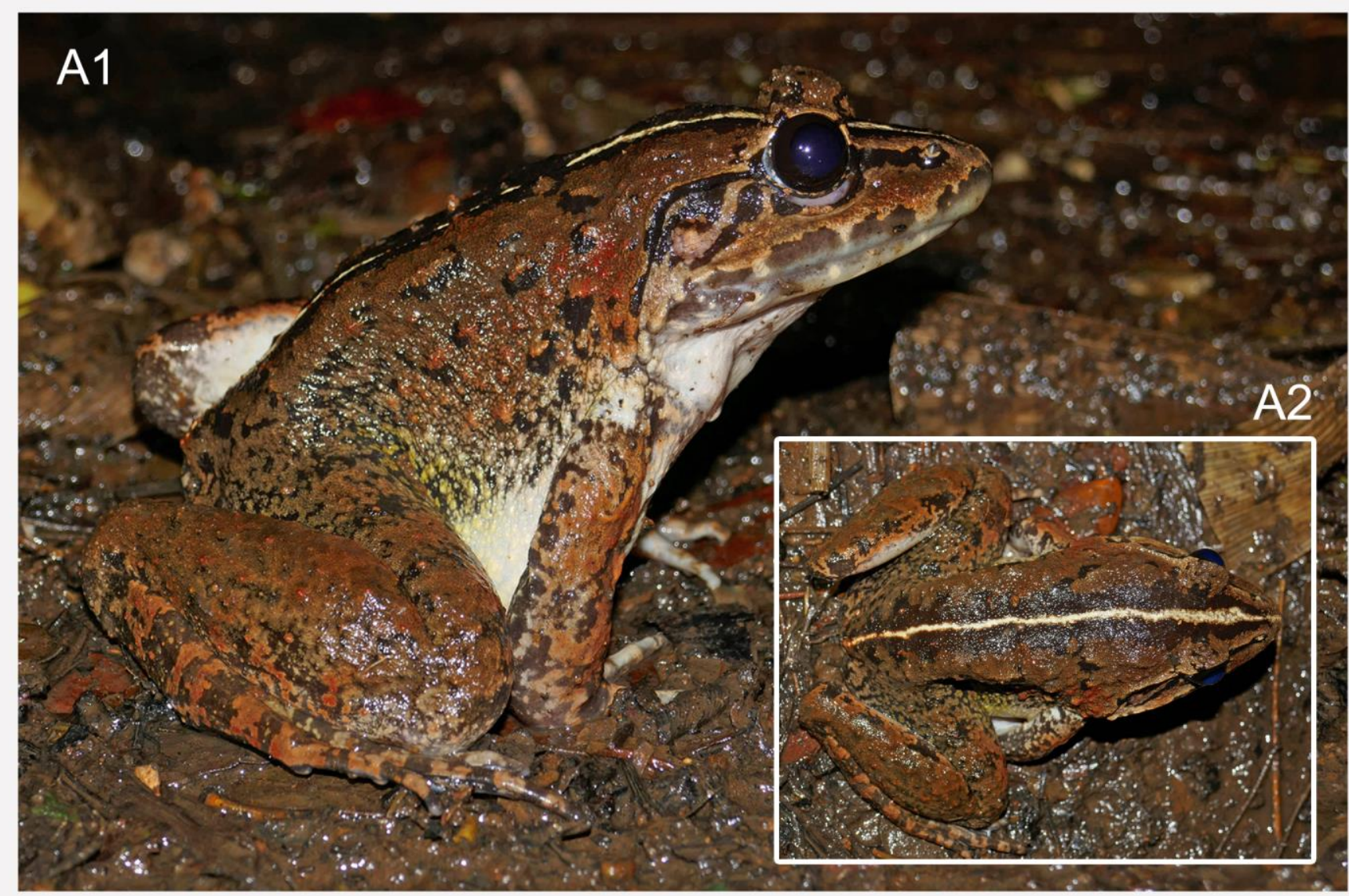

Figure 1. (A1) Lateral and (A2) dorsal aspects of the body of Limnonectes macrodon specimen from Bali

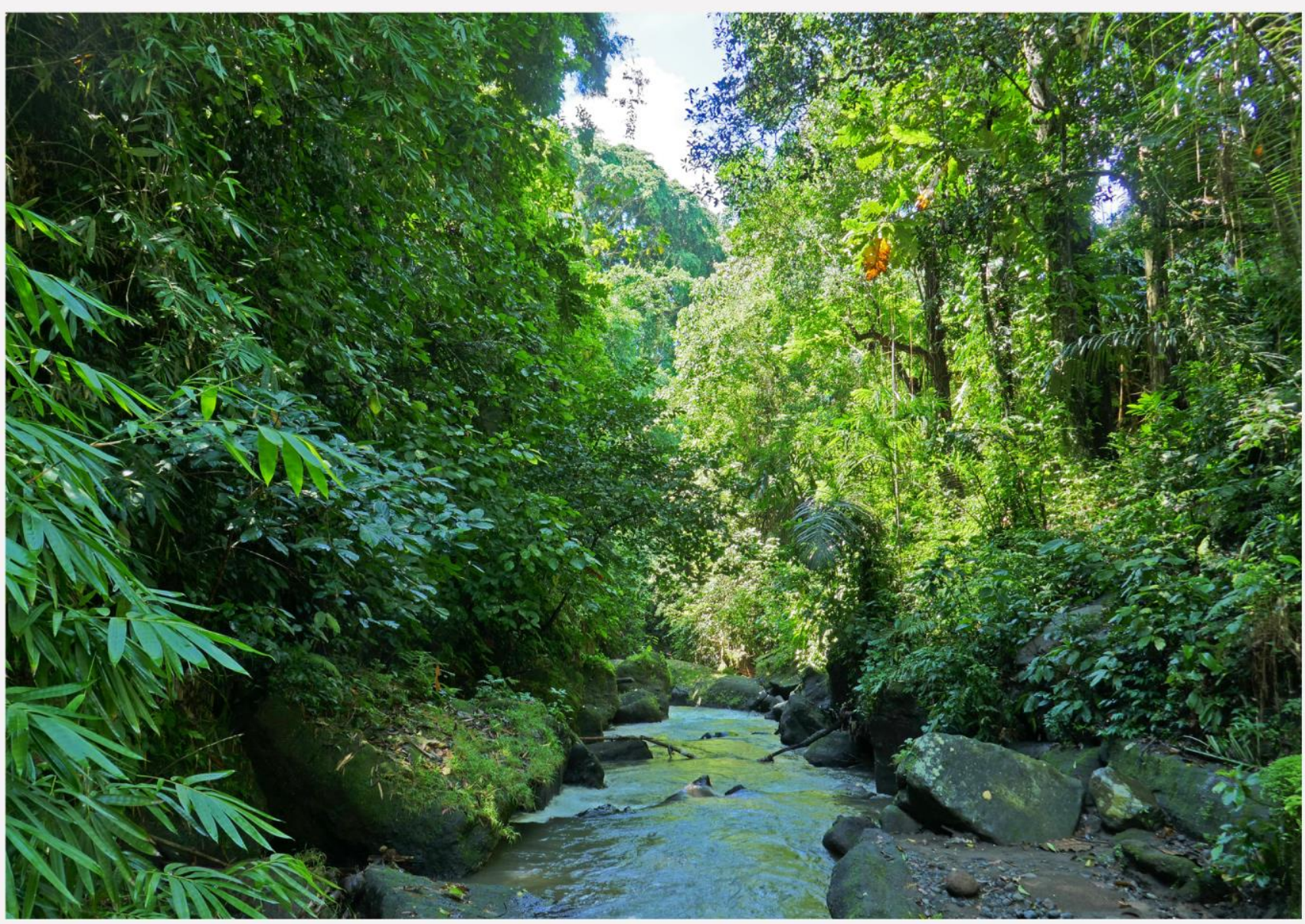

Figure 2. Stream in the closed-canopy forest where the Limnonectes macrodon specimen was observed 